Nama ; Rismayanti

Nim ; 90100118033

Kelas Ekonomi Islam/A

\title{
Kritik Adam Smith Terhadap Mercantilisme
}

Pertama untuk memasuki pembahasn tentang kritik adam smith kita harus mengetahui terlebih dahulu yaitu biografi serta konsep Adam smith, Jadi Adam Smith ini adalah seorang yang tinggal di Negara inggris dia itu seorang ahli yang mengenai tentang perekonomian yang pertama kali di dunia (Cuk Anata 2016). Selanjutnya berbicara tentang teori-teori adam smith ini ada membahas tentang tangan-tangan yang tak terlihat atau disebut dengan insible hand pada perekonomian ini tidak ada campur tangan pemerintah biar sedikitpun, jadi masyarakat ini bebas melakukan apa saja yang mereka inginkan ,Selanjutnya terkait dengan kebebasan dan pasar bebas jadi seorang mercantilisme pada adam smith ini merupakan diberikan kebebasan dalam melakukan sesuatu hal yang mereka inginkan ,dan terkait dengan pasar bebas ini jika tidak ada campur tangan pemerintah bisa juga dikatakan bebas menjual suatu produk dan mengambil keuntungan yang sebanyak banyaknya dalam artian kata ada sistem pemasaran yang secara bebas didalamnya( Junedi Safitri, Abdul Muhaimin, Fakhri,2017)

Berbicara tentang kritik merkantilisme yang awalnya adam smith ini mengkritik tentang pada perekonomian pasar tidak boleh adanya campur tangan dari pemerintahan jadi seseorang dalam masyarakat itu diberikan kebebasan melakukan segala aktifitas yang menyangkut tentang perekonomian ini dan adam smith beranggapan juga di bolehkan sistem permintaan dan penawaran ini yang mengatur oleh sistem ekonomi (Ade Perlauangan,2014). Kritikan selanjutnya mengenai tentang pada saat adanya adam smith ini dia mengkritisi juga tentang perdagangan-perdagangan internasional(Rustam Dahar,2012) dan mengenai tentang perekonomian ini perlu adanya memperbanyak ekspor dari pada impor sehingga dapat menimbulkan tentang memperbanyak atau memperkaya yang di lingkup.Suatu daerah setiap individu yang menginginkan tentang mendapatkan keuntungan yang sebanyak-banyaknya perlu adanya perdagangan yang dilakukan secara baik dan transparan(Safitri and Fakhri,2017) Selanjutnya dalam kritikan merkantilisme ini tentang kelebihan yang dimiliki oleh setiap daerah daerah yang berbeda dan adam smith juga ini melakukan suatu hal bahwa perekonomian harus 
dilakukan dengan baik daripada mengikuti tanggapan yng bukan nyata merkantilisme dan pada kritikan adam smith juga menyatakan bahwa dalam melakukan suatu perekonomian dipasar maupun ditempat-tempat lain perlu adanya daya saing, karena didalam melakukan suatu perdagangan setiap pedagang mampu melakukan persaingan antar sesama manusia ataupun dengan sesama pedagang tapi dalam melakukan suatu hal atau persaingan harus ada hal yang kita perlu ketahui bahwa dalam melakukan suatu perdagangan dan bersaing tidak boleh menipu orang lain serta antar konsumen maupun pedangan tidak boleh adanya suatu kedzholiman diantara mereka(Handito hadi,2008).

\section{DAFTAR PUSTAKA}

Safitri, J., \& Fakhri, A. (2018). ANALISIS PERBANDINGAN PEMIKIRAN ABU â€ UBAID AL-QASIM DAN ADAM SMITH MENGENAI PERDAGANGAN INTERNASIONAL.

Millah: Jurnal Studi Agama, 1(1), 85-98.

Joewono, H. H. (2008). THE 5 STRATEGY TO ENHANCE INDONESIA'S AGRO- BASED INDUSTRY COMPETITIVENESS. Journal of Indonesian Economy and Business, 23(1), 19.

KAH, R. D. (2012). Teori Invisible Hand Adam Smith Dalam Perspektif Ekonomi Islam. Economica: Jurnal Ekonomi Islam, 2(2), 57-70.

Nasution, A. P. (2014). Kaum Saudagar Dalam Lingkaran Kekuasaan

Negara. BENING, 1(2).

Safitri, J., \& Fakhri, A. (2018). Analisis Perbandingan Pemikiran Abu Ubaid AlQasim dan Adam Smith Mengenai Perdagangan Internasional. Millah: Jurnal Studi Agama, 1(1), 85-98.

Wijaya, C. A. (2009). Filsafat Ekonomi Adam Smith. Jurnal Filsafat, 19(1). 